\begin{tabular}{|l|l|}
\hline JURNAL ABDI MASYA & Volume 1 Nomor 3 \\
November 2021 \\
E-ISSN : 2774-2849 $157-163$ \\
P-ISSN : 2774-2881 & Website: https://jurnal.sttw.ac.id/index.php/abma/about \\
\hline
\end{tabular}

\title{
PEMBERDAYAAN INDUSTRI KERAJINAN EDUKATIF DARI KAYU "BERSINAR" DI DESA TEGALREJO KEC. TRUCUK KAB. KLATEN
}

\section{EMPOWERMENT OF THE EDUCATIONAL CRAFT INDUSTRY FROM WOOD "BERSINAR" IN TEGALREJO VILLAGE, KEC. TRUCUK KAB. KLATEN}

\author{
Teguh Wiyono ${ }^{1 *}$, Dita Anggi Purbasari ${ }^{2}$, Siswanto ${ }^{3}$ \\ ${ }^{1}$ Program Teknik Mesin, Politeknik Pratama Mulia, Surakarta \\ ${ }^{2}$ Program Studi Manajemen Informatika, Politeknik Pratama Mulia, Surakarta \\ ${ }^{3}$ Program Teknik Mesin, Politeknik Pratama Mulia, Surakarta \\ *Email: teguhwiyono487@gmail.com
}

\begin{abstract}
ABSTRAK
Perberdayaan kerajinan edukatif dari kayu yang digunakan untuk pertumbuhan kecerdasan anak-anak TK maupun PAUD adalah usaha berjenis Home Industry ini telah lama ditekuni oleh masyarakat di Desa Sajen Kecamatan Trucuk Kabupaten Klaten. Walau tidak seluruh masyarakatnya menekuni pekerjaan sebagai pengrajin tetapi pekerjaan kreatif ini sudah menjadi salah satu simbol desa tersebut dan ikut membesarkan nama Klaten sebagai salah satu kabupaten penghasil kerajinan di Jawa Tengah. Produk dari Kerajinan edukatif dari kayu sendiri banyak macamnya dan bervariasai. Kerajinan edukatif dari kayu termasuk usaha yang sudah berkembang sejak lama dan kini semakin ramai dan menunjukkan kemajuan yang sangat pesat. Permasalahan yang dihadapi saat ini adalah mesin yang digunakan untuk produksi mesin gergaji dan mesin gerinda pembentuk kerajinan edukatif cara pengoperasiannya sangat mudah dengan cara menekan tombol on maupun off sehingga jumlah produksinya terbatas padahal pemesanan kerajinan tersebut tiap bulannya meningkat pesanan datang dari luar daerah sampai luar jawa terutama pada saat tahun ajaran baru.

Direktorat Riset dan Pengabdian kepada Masyarakat, Ditjen Penguatan Risbang Kementrian Pendidikan dan Kebudayaan dengan programnya yang berupa PKM dengan ini membantu para pengrajin edukatif dengan melakukan pendampingan dana guna mengatasi permasalahan selama ini dengan pembuatan teknologi tepat guna mesin gergaji Router pembuat profil dan mesin gerinda serbaguna yang cara kerjanya secara elektrik. Politeknik Pratama Mulia Surakarta mencoba menerapkan Tri Dharma Perguruan Tinggi terutama dalam Pengabdian kepada masyarakat yang bekerja sama dengan Kemendikbud dalam pelaksanaan pembuatan mesin dan kegiatan lainnya guna membatu para pengrajin edukatif untuk mengatasi permasalahannya selama ini. Terlaksananya program ini secara khusus dapat meningkatkan produksi kerajinan edukatif sampai 140\%, sedangkan dalam pengerjaan finishing peningkatan kwalitas sampai 25\%, diharapkan dengan program PKM ini dalam skala Nasional akan meningkatkan pendapatan perkapita daerah.
\end{abstract}

Kata kunci : Pengrajin edukatif, mesin teknologi tepat guna, kualitas, peningkatan, produktifitas

\section{ABSTRACT}

Empowerment of educational crafts from wood used for the growth of the intelligence of kindergarten and PAUD children is a Home Industry type business that has long been occupied by the community in Sajen Village, Trucuk District, Klaten Regency. Although not all of the people work as craftsmen, this creative work has become one of the symbols of the village and helped raise the name of Klaten as one of the craft-producing districts in Central Java. There are many kinds of products from wooden educational crafts and they were varied. Educational crafts from wood are businesses that have been growing for a long time and are now getting busier and showing very rapid progress. The problem faced at this time is that the machines used for the production of saws and grinding machines forming educational crafts are very simple, so the amount of production was limited even though the orders for these crafts are increasing every month, orders come from outside the region to outside Java, especially during the new school year.

Directorate of Research and Community Service, Directorate General of Risbang Strengthening of the Ministry of Education and Culture with its program in the form of PKM hereby assists educative craftsmen by 
providing financial assistance to overcome problems so far by making appropriate technology for sawing machines, profiling routers and versatile grinding machines that works electrically. The Pratama Mulia Polytechnic of Surakarta tries to apply the Tri Dharma of Higher Education, especially in community service in collaboration with the Ministry of Education and Culture in the implementation of making machines and other activities to help educational craftsmen to overcome their problems so far. The implementation of this program specifically improves skills that support productivity and can increase the income of educational craftsmen and their groups in Tegalrejo, Sajen Village, Trucuk District, it is hoped that this PKM program on a national scale will increase regional per capita income.

Keywords: Educational craftsmen, appropriate technology machines, quality, improvement, productivity

\section{Submit: 2 November 2021 Accepted: 12 November 2021 Published: 26 November 2021}

\section{PENDAHULUAN}

Pengolahan limbah produksi mebel dapat dijadikan sebagai peluang usaha. Salah satu bentuk pemanfaatan limbah mebel menjadi produk bernilai ekonomi, yaitu dengan pembuatan APE (Alat Permainan Edukatif) dari potongan kayu limbah mebel. Bentuk APE kayu tersebut dapat berupa puzzle bentuk, bentuk geometri, puzzle angka, balok, dan lain-lain sesuai dengan kebutuhan/pesanan. Untuk memaksimalkan pemanfaatan yang memiliki nilai jual tinggi, diperlukan kreativitas dalam menciptakan serta manajemen pemasaran yang baik. Menurut Khutobah dkk.[1] pada kenyataanya industri kecil dan kerajinan merupakan industri yang tahan banting terhadap keadaan ekonomi yang tidak menentu seperti saat ini. Menurut Merari (2019) [2] Kampung Tegalrejo Desa Sajen Kecamatan Trucuk Kabupaten Klaten, Jawa Tengah. Di desa tersebut masyarakatnya sebagian besar sebagai usaha kreatif yaitu kerajinan edukatif dari kayu yang digunakan untuk pertumbuhan kecerdasan anak-anak TK maupun PAUD. Usaha berjenis Home Industry ini telah lama ditekuni oleh masyarakat di Desa itu. Walau tidak seluruh masyarakatnya menekuni pekerjaan sebagai pengrajin edukatif dari kayu tetapi pekerjaan kreatif ini sudah menjadi salah satu simbol desa tersebut dan ikut membesarkan nama Klaten sebagai salah satu kabupaten penghasil kerajinan di Jawa Tengah. Produk dari Kerajinan edukatif dari kayu sendiri banyak macamnya dan bervariasai. Kerajinan edukatif dari kayu termasuk usaha yang sudah berkembang sejak lama dan kini semakin ramai dan menunjukkan kemajuan yang sangat pesat. Di desa tersebut salah satu yang mengembangkan kerajinan edukatif dari kayu diantaranya adalah Bapak Abid (45 th) dengan papan nama pengrajin edukatif "Bersinar " alamat Kapung Tegalrejo Rt.05/01 Desa Sajen Kecamatan Trucuk, Kabupaten Klaten.

Permasalahan yang dihadapi saat ini adalah mesin produksi yang berbentuk mesin gergaji, mesin bor dan gerinda pembentuk kerajinan masih manual sehingga jumlah produksinya terbatas padahal pemesanan kerajinan tersebut tiap bulannya meningkat pesanan datang dari luar daerah dan sudah merambah ke luar provinsi, sementara ini cara mengatasi pemesanan terutama tahun ajaran baru dengan cara lembur guna mencukupinya, walaupun sudah lembur tetapi tidak semua pesanan dari luar dapat terpenuhi karena keterbatasan alat. Begitu juga dari finishing produk masih memakai mesin gerinda yang sederhana sehingga hasilnya kurang rapi dan tidak merata maka hal ini akan berpengaruh terhadap nilai jual dari kerajinan edukatif dari kayu itu sendiri. Hal ini tentu kurang efektif disamping hasil yang tidak sesuai yang diinginkan dalam hal kapasitas produksi apabila menambah tentu menambah tenaga kerja lagi sehingga akan menambah biaya produksi.

Penjualan kerajinan edukatif dari kayu ini sementara hanya melayani pasar lokal dan luar provinsi jawa tengah, sementara ini yang banyak memesan kerajinan dari luar jawa adalah Kalimantan. Sulawesi dan Sumatra, tetapi tidak menutup kemungkinan akan mengembangkan kerajinan tersebut untuk ekspor ke manca negara (Sumber : Survey Di Kampung Tegalrejo Rt.05/01 Desa Sajen Kecamatan Trucuk, Kabupaten Klaten - Jawa Tengah). Pengrajin edukatif akan meningkatkan produksinya yang berupa kerajinan edukatif supaya dapat memenuhi permintaan dari luar kota terpenuhi, Pengrajin memerlukan mesin teknologi tepat guna yang standar produk sehingga waktu yang dibutuhkan cepat tanpa harus mengurangi tenaga kerja, dengan demikian pengrajin membutuhkan mesin teknologi tepat guna. Politeknik Pratama Mulia Surakarta sebagai 
Perguruan Tinggi yang menerapkan tentang Darma Pengabdian kepada Masyarakat harus mampu membantu pengrajin dalam memberikan bantuan berupa mesin teknologi tepat guna diharapkan nantinya dapat meningkatkan produksi maupun pendapatan pengrajin edukatif dari kayu tersebut.

\section{METODE PELAKSANAAN}

Pelaksanaan program Kemitraan masyarakat (PKM) ini diawali dengan sosialisasi dilapangan serta pemetaan permasalahan yang ada di pengarjin edukatif Di Kampung Tegalrejo Rt.05/01 Desa Sajen Kecamatan Trucuk, Kabupaten Klaten. Hasil diskusi dan pemetaan permasalahan yang ada di pengrajin tersebut dijadikan permasalahan yang harus segera dilakukan diantaranya sebagai berikut :

Pembuatan mesin gergaji router pembuat profil dan mesin gerinda multiguna yang cara kerjanya secara elektrik kedua mesin tersebut dibuat di laboratorium Teknik mesi Politeknik Pratama Mulia Surakarta sekarang kedua mesin tersebut sudah diserahkan pada Pengrajin edukatif dari kayu "Bersinar" Di Kampung Tegalrejo Rt.05/01 Desa Sajen Kecamatan Trucuk, Kabupaten Klaten.

Kedua mesin tersebut sekarang sudah digunakan untuk menproduksi kerajinan edukatif dari kayu, tinggal waktu untuk menuju sukses dengan peningkatan produksi kerajinan edukatif dari kayu tersebut.

Kegiatan pelatihan Finishing produk kerajinan edukatif dari kayu dengan cara air brush dan Pelatihan pembuatan WEB guna memasarkan produk kerajinan edukatif dari kayu melalui onlie serta Pelatihan manajemen dan administrasi usaha, administrasi pembukuan sederhana dan manajemen pemasaran akan di laksanakan secara bertahap karena menunggu waktu dan kesepakatan antara ketua pelaksana program PKM dengan ketua Pengrajin edukatif dari kayu karena masih dalam situasi pandemik covid 19 ini,

\section{HASIL DAN DISKUSI}

Program kemitraan masyarakat ini menghasilkan mesin gergaji router dan mesin gerinda yang berfungsi untuk meringankan beban bagi pengrajin edukatif dari kayu guna meningkatkan produksi kerajinan sehingga nantinya dapat meningkatkan pendapatan bagi pengrajin dan keluarganya serta sebagai wacana bagi industri kecil lainya, bahwa mesin ini dapat digunakan untuk pertukangan, pengrajin handicraft dan sejenisnya yang produksinya bahandasar dari kayu. Mesin ini dalam proses pemakaiannya sangat mudah, sederhana dengan tingkat keselamatan kerja yang terjamin dan perawatannya tidak terlalu sulit.

\section{Dampak Ekonomi dan Sosial}

Dampak Ekonomi dan sosial yang dirasakan diantaranya peningkatan produktifitas pembuatan kerajian edukatif dari kayu, sehingga dapat meningkatkan pendapatan bagi pengrajin beserta anggotanya, dan peningkatan order bagi pemilik bengkel teknologi tepat guna, dalam pembuatan mesin gergaji router serbaguna dan mesin gerinda yang digunakan pada pengrajin edukatif dari kayu ini Biaya yang ditanggung untuk kepemilikan mesin semakin murah. Nilai ekonomis serta hasil kerajinan edukatif ini semakin baik dan menarik sehingga dapat meningkatkan nilai jual dari kerajinan edukatif tersebut. Secara umum terlaksana program ini meningkatkan kesejahteraan masyarakat kalangan menengah ke bawah dan meningkatkan pendapatan, khususnya para pengrajin edukatif dari kayu dan perbengkelan di daerah tersebut.

Tabel. 1 Spesifikasi Mesin gergaji yang di rekayasa

\begin{tabular}{lll}
\hline Daya mesin & $:$ & $1 \mathrm{PK}$ \\
Putaran mesin & $:$ & $1400 \mathrm{rpm}$ \\
Kapasitas mesin & $:$ & $2.5 \mathrm{buah} / 60$ Menit \\
Lebar mesin & $:$ & $800 \mathrm{~mm}$ \\
Panjang mesin & $:$ & $950 \mathrm{~mm}$ \\
Tinggi & $:$ & $900 \mathrm{~mm}$ \\
\hline
\end{tabular}




\section{A. Perbandingan Ekonomis}

Tabel. 2 Perbandingan pemakaian Mesin gergaji manual dengan Mesin gergaji yang direkayasa

\begin{tabular}{llll}
\hline No & Jenis Kegiatan & \multicolumn{2}{c}{ Proses pengolahan } \\
\cline { 3 - 4 } & & \multicolumn{1}{c}{ Mesin manual } & \multicolumn{1}{c}{ Mesin yang direkayasa } \\
\hline 1 & Proses Penggergajian & Piringan gergaji & Piringan gergaji baja \\
2 & Waktu pengolahan & 15 Menit & 6 Menit \\
3 & Daya & $1 \mathrm{PK}$ & $1 \mathrm{PK}$ \\
4 & Hasil Pengerjaan & $70 \%$ & $95 \%$ \\
5 & Jumlah Reducer & - & 1 \\
6 & Produksi Kerajinan & $1 / 60$ menit & $2.3 / 60$ menit \\
7 & Biaya yang ditanggung & $50.000 /$ bulan & $30.000 /$ bulan \\
8 & Perawatan & - Rumit & Mudah \\
\hline
\end{tabular}

Dari tabel 2 di atas didapat perbandingan ekonomis mesin gergaji pada pengrajin edukatif yang direkayasa dalam produksi kerajinan rumah tangga mengalami peningkatan produksi sebesar $140 \%$, dengan ketentuan pisau yang digunakan 1 buah tingkat kehalusan dalam finishing meningkat 25\% sedangkan biaya operasional mengalami penurunan sebesar $40 \%$, tetapi ada peningkatan dalam penggunaan daya motor listrik sama 1 PK untuk penggerak utamanya.

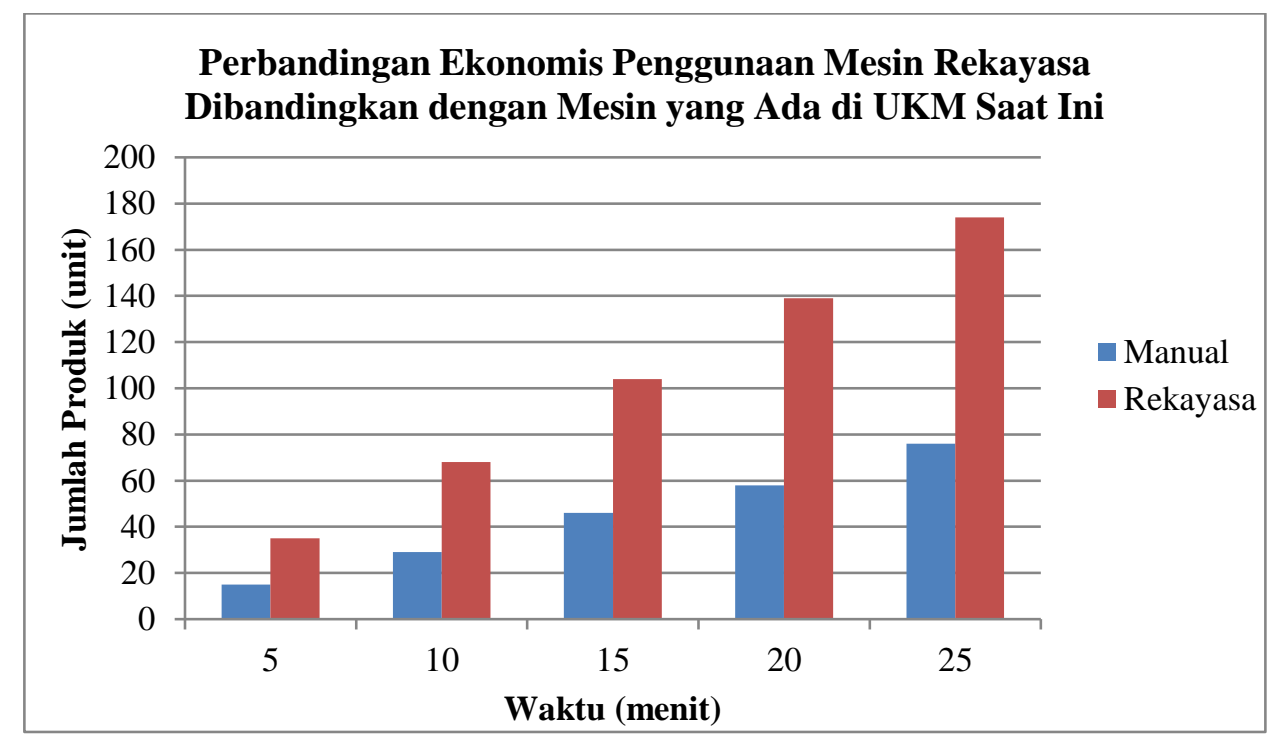

Gambar 1. Perbandingan penggunaan mesin

Dari gambar 1. Grafik perbandingan hasil pengerjaan mesin gergaji yang direkayasa dengan mesin gergaji yang ada di pengrajin saat ini didapat peningkatan produksi dari waktu pelaksanaan ada peningkatan produksi rata-rata sebesar $130 \%$ dari waktu yang sama, sehingga mesin yang telah diberikan pada pengajin saat ini sudah digunakan untuk produksi setiap harinya 


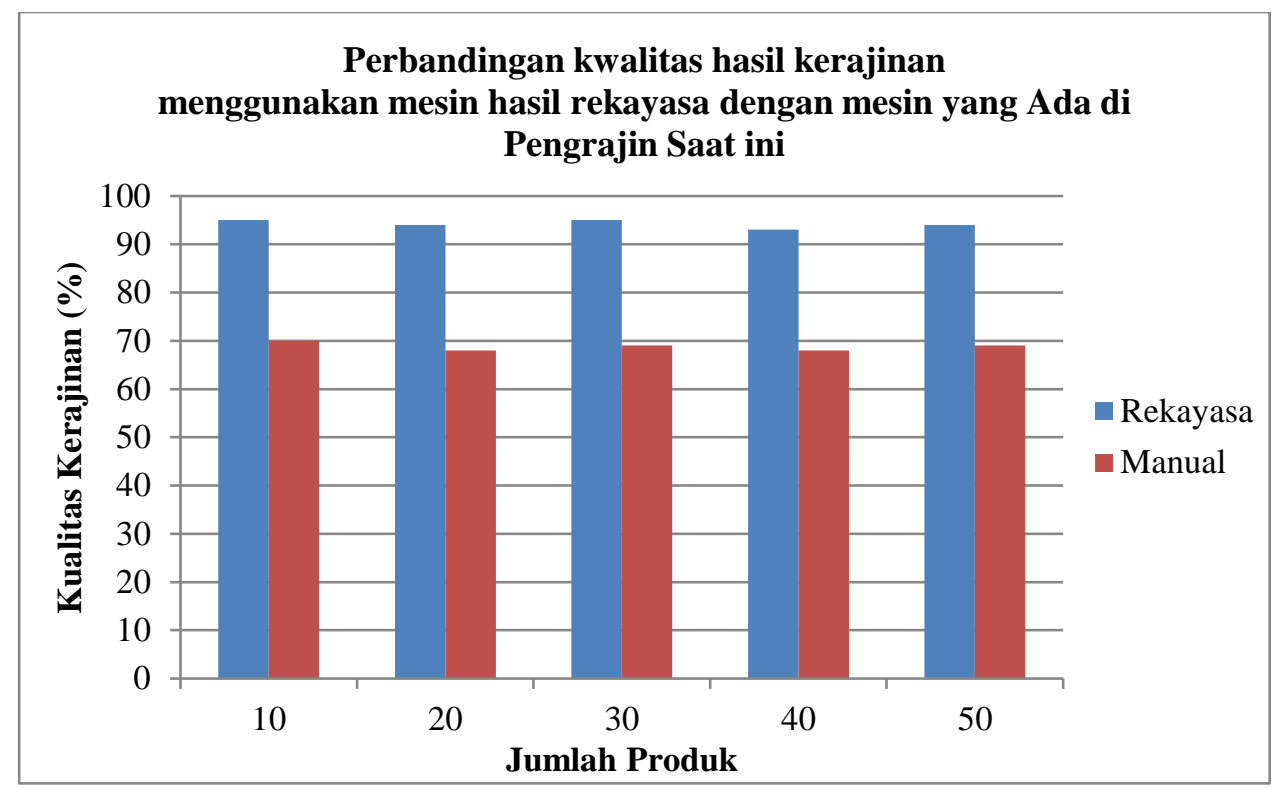

Gambar 2. Perbandingan kwalitas hasil kerajinan

Gambar 2 yang menunjukkan perbandingan kwalitas pengerjaan terutama kehalusan kayu dalam finishing dari hasil pengerjaan mesin gergaji yang direkayasa dengan mesin gergaji yang ada di pengrajin saat ini didapat peningkatan kualitas sebesar dari waktu pelaksanaan sebesar $60 \%$ dari waktu yang sama, sehingga mesin yang telah diberikan pada pengrajin saat ini sudah layak untuk dapat produksi setiap harinya.

Tabel 3. Spesifikasi Mesin Gerinda yang di rekayasa

\begin{tabular}{lll}
\hline Daya mesin & $:$ & $1.5 \mathrm{PK}$ \\
Putaran mesin & $:$ & $1450 \mathrm{rpm}$ \\
Kapasitas mesin & $:$ & 7 Batang / 1 Menit \\
Lebar mesin & $:$ & $500 \mathrm{~mm}$ \\
Panjang mesin & $:$ & $800 \mathrm{~mm}$ \\
Tinggi Mesin & $:$ & $1600 \mathrm{~mm}$ \\
\hline
\end{tabular}

Tabel. 4 Perbandingan Pemakaian Mesin Gerinda yang Ada di Pengrajin dan Mesin yang dibuat

\begin{tabular}{llcc}
\hline \multirow{2}{*}{ No } & \multicolumn{1}{c}{ Jenis Kegiatan } & \multicolumn{2}{c}{ Proses pengolahan } \\
\cline { 3 - 4 } & & Mesin di Pengrajin & $\begin{array}{c}\text { Mesin yang } \\
\text { Direkayasa }\end{array}$ \\
\hline 1 & Proses Penggergajian & Satu batu gerinda & Dua batu gerinda \\
2 & Waktu Produksi & 3 Buah / Menit & 7 buah/ Menit \\
3 & Daya & 1,5 PK & 1.5 PK \\
4 & Hasil Pengerjaan & $70 \%$ kehalusan & $95 \%$ kehalusan \\
5 & Biaya yang ditanggung & $100.000 /$ bulan & $60.000 /$ bulan \\
6 & Perawatan & Rumit & Mudah \\
\hline
\end{tabular}

Dari tabel 4 diatas didapat perbandingan ekonomis mesin gerinda yang ada di pengrajin dan mesin gerinda yang direkayasa dalam produksi kerajinan edukatif mengalami peningkatan produksi sebesar 190\%, dengan ketentuan batu gerinda yang digunakan 2 buah tingkat kehalusan dalam 
finishing meningkat $30 \%$ sedangkan biaya operasional mengalami penurunan sebesar $40 \%$, penggunaan daya motor listrik sama-sama 1,5 Pk.

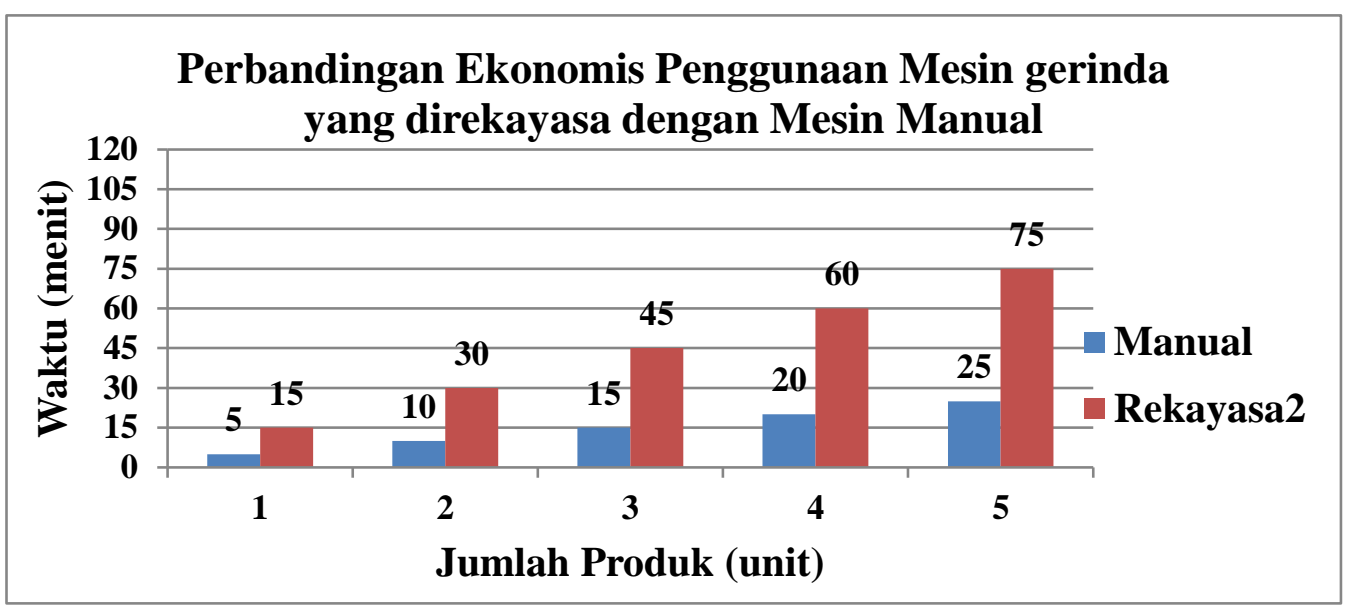

Gambar 3. Perbandingan penggunaan mesin gerinda

Dari gambar 3. Grafik perbandingan hasil pengerjaan mesin gerinda yang direkayasa dengan mesin gerinda yang ada di pengrajin saat ini didapat peningkatan produksi dari waktu pelaksanaan ada peningkatan produksi rata-rata sebesar $190 \%$ dari waktu yang sama, sehingga mesin yang telah diberikan pada pengrajin saat ini sudah digunakan produksi setiap harinya.

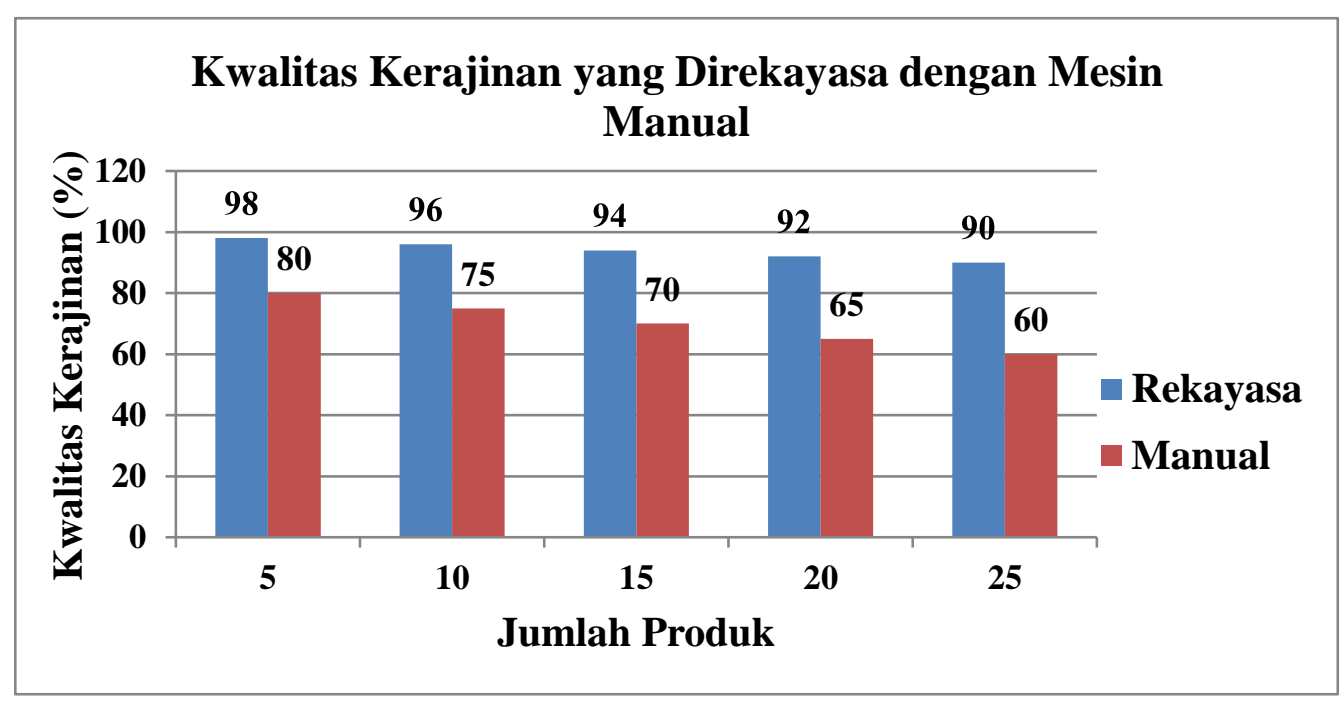

Gambar 4. Perbandingan kwalitas hasil kerajinan

Gambar 4. yang menunjukkan perbandingan kwalitas pengerjaan kerajinan terutama kehalusan kayu dalam finishing dari hasil pengerjaan mesin gerinda yang direkayasa dengan mesin gerinda yang ada di pengrajin saat ini didapat peningkatan kualitas sebesar dari waktu pelaksanaan sebesar $30 \%$ dari waktu yang sama, sehingga mesin yang telah diberikan pada pengrajin edukatif saat ini layak untuk dapat digunakan produksi setiap harinya. 


\section{KESIMPULAN}

Dari hasil pelaksanaan Program kemitraan masyarakat mesin gergaji router dan mesin gerinda maka dapat diambil kesimpulan sebagai berikut:

a. Mesin Gergaji router, dapat bekerja dengan baik, dalam produksi setiap harinya mengalami peningkatan produksi sampai $140 \%$, sedang dalam pengerjaan finishing mengalami peningkatan kwalitas produk sampai $25 \%$, sedangkan biaya operasional mesin mengalami penurunan sebesar $40 \%$.

b. Mesin Gerinda dapat bekerja dengan baik, dalam produksi kerajinan edukatif mengalami peningkatan produksi sampai $190 \%$, sedang dalam pengerjaan finishing mengalami peningkatan kwalitas produk sampai 30\%, sedangkan biaya operasional mesin mengalami penurunan sebesar $40 \%$.

c. Pengelolan manajemen sudah berjalan dengan baik terbukti sudah tertibnya pembukuan laporan tiap minggu dan tiap bulannya walaupun kadang-kadang lupa untuk memasukkan dalam pembukuan perlu penyempurnaan dalam monitoring didalam pembuatan laporan pembukuan sederhana.

\section{UCAPAN TERIMA KASIH}

a. Direktorat Riset dan Pengabdian kepada Masyarakat, Ditjen Penguatan Risbang Kementrian Pendidikan dan Kebudayaan kami mengucapkan terima kasih yang telah memberikan dukungan pendanaan pada Program kemitraan masyarakat ini, sehingga kegiatan yang kami rencanakan dapat berjalan sesuai dengan rencana

b. Kepada Politeknik Pratama Mulia Surakarta, kami mengucapkan terima kasih yang sebesarbesarnya, karena dengan dukungannya secara moril dan fasilitas yang diberikan kepada kami, sehingga dapat melaksanakan kegiatan program Program Program kemitraan masyarakat ini.

c. Kepada Mitra Pengrajin edukatif "bersinar" Desa Sajen Kecamatan Trucuk, Kabupaten Klaten kami mengucapkan banyak terima kasih atas kerjasamanya dalam mendukung kegiatan Program Program kemitraan masyarakat ini Atas ide-idenya masukan dari mitra tersebut maka program dapat berjalan dengan baik. Pada kesempatan ini kami juga didukung oleh mitra dari bengkel yang siap akan menggandakan mesin-mesin yang kami rekayasa.

\section{DAFTAR PUSTAKA}

[1] Khutobah, Luh Putu Indah Budyawati, Zetti Finali, "Pemanfaatan Limbah Produksi Mebel Menjadi Alat Permainan Edukatif Dengan Pemasaran Berbasis Websote di Desa Kemuning Lor Jember" e-Journal Warta Pengabdian, Volume II Issue 4,pp177-185 Maret 2018

[2] Merari, "Perancangan Produk Mainan Menggunakan Material Limbah Rotan" Calyptra : journal Ilmiah Mahasiswa Universitas Surabaya, Volume 8 No.1 2019

[3] Nusrotus Saidah, Yunita Eka Farida, Jati Widagdo, "Pemanfaatan Limbah Kayu Melalui Puzzle Wayang sebagai Media Pengenalan Budaya Untuk anak usia Dini, E- Dimas Jurnal Pengabdian Kepada Masyarakat, 11(1), 66-70 2020

[4] Richard Jonathan, Roni Anggoro, "Fasilitas Pelatihan Industri Kreatif Kerajinan Kayu di Surabaya" Journal eDimensi Arsitektur Volume VIII No.1 2020 